\title{
Antimicrobial activity of four Valeriana (Caprifoliaceae) species endemic to the Venezuelan Andes
}

\author{
María Rondón ${ }^{1}$, Judith Velasco², Janne Rojas ${ }^{1}$, Luis Gámez ${ }^{3}$, Gudberto León ${ }^{4}$, Efraín Entralgo ${ }^{4}$ \\ \& Antonio Morales ${ }^{1}$ \\ 1. Organic Biomolecular Research Group. Faculty of Pharmacy and Bioanalysis. University of Los Andes, Mérida, \\ Venezuela; rondonr@ula.ve,janner@ula.ve, lostopes@yahoo.es \\ 2. Microbiology and Parasitology Department, Faculty of Pharmacy and Bioanalysis. University of Los Andes, Mérida, \\ Venezuela; judivel@ula.ve \\ 3. Faculty of Forestry and Environmental Science. University of Los Andes, Mérida, Venezuela; lgamez@ula.ve \\ 4. Faculty of Economic and Social Sciences, Statistics School, University of Los Andes, Mérida, Venezuela; \\ gudberto@ula.ve,entralgo@ula.ve
}

Received 11-II-2018. Corrected 23-V-2018. Accepted 25-VI-2018.

\begin{abstract}
Valeriana L. genus is represented in Venezuela by 16 species, 9 of these are endemic of Venezuelan Andes growing in high mountains at 2800 masl. In this investigation, four species were analyzed in order to determine the main secondary metabolites and antimicrobial activity of extracts obtained from aerial parts of Valeriana parviflora, V. rosaliana, V. triplinervis and V. phylicoides. Alkaloids, flavonoids, tannins, sterols, triterpenoids and saponins were qualitatively observed in all methanolic extracts tested. The color intensity or a precipitate formation was used as analytical response to these tests. Antimicrobial activity was evaluated against Gram positive, Gram negative bacterial strains and yeast, using disc diffusion method. $N$-hexane extracts of $V$. triplinervis and V. rosaliana showed the highest efficiency against Staphylococcus aureus, exhibiting inhibition zones of $16 \mathrm{~mm}$ and $15 \mathrm{~mm}$; MIC (Minimal Inhibition Concentration) values were observed at $116 \mathrm{mg} / \mathrm{mL}$ and $150 \mathrm{mg} / \mathrm{mL}$, respectively. Dichloromethane and methanolic extracts of $V$. triplinervis and methanolic extract of $V$. rosaliana showed a rather moderate activity (MIC between 200 to $316 \mathrm{mg} / \mathrm{ml}$ ) but a very weak antibacterial activity was observed in $V$. phylicoides and V. parviflora extracts (MIC $>420 \mathrm{mg} / \mathrm{mL}$ ). None of the extracts assayed in this investigation showed any activity against Candida albicans and Candida krusei. Statistical analysis showed no significant differences on the different polarity extracts assayed with respect to antimicrobial activity against $S$. aureus $(\mathrm{P}>0.10)$, however it was observed significant differences between the Valeriana species analyzed $(\mathrm{P}<0.10)$ in relation to the minimal inhibitory concentration (MIC). Rev. Biol. Trop. 66(3): 1282-1289. Epub 2018 September 01.
\end{abstract}

Key words: Valeriana; antimicrobial activity; phytochemical; Venezuela.

Valeriana genus (Caprifoliaceae, subf. Valerianoideae) comprises about 281 species distributed around the world being a representative genus for South America Andes (Bell \& Dologhue, 2005). In Venezuela, 16 species have been reported, nine of these are endemic from the Andean Paramo (Xena, 1993). Regarding traditional medicine, Valeriana species are widely used by its sedative, hypnotic, anxiolytic and antidepressant properties. Thus, many phytomedicinal products based on
Valeriana officinalis L. extracts or powder are commercialized as capsules, tablets and tinctures, especially from the roots of this species (Patoĉka \& Jakl, 2010). Due to the frequent use of these commercial products, $V$. officinalis, has been subject to numerous investigations in order to establish the chemical composition and pharmacological activity, particularly in central nervous system. Valepotriate sesquiterpenes and other compounds present in essential oil obtained from $V$. officinalis might also be 
responsible for this activity (Houghton, 1988; Houghton, 1998; Miyasaka \& Soares 2006; Celis, Rincón, Guerrero, 2007). Recently, a group of researchers reported that antidementia activity attributed to sesquiterpenes and monoterpenes isolated from $V$. officinalis var. latiofolia mediate its action probably through acetylcholinesterase inhibition (Chen et al., 2016). Neuroprotective activity of $V$. wallichii and $V$.jatamansi with effect against Parkinson's disease has also been observed (Sridharan et al., 2015; Tan et al., 2016).

Cytotoxic, antioxidant, antispasmodic, anthelmintic and antibacterial activity were also detected on extracts obtained from some Valeriana species (Gilani, Khan, Jabeen, Subhan, \& Ghafar, 2005; Sati, Khulbe, \& Joshi, 2011; Potdar, Lole, \& Patil, 2011; Bhatt et al., 2012; Aydin, Dikmen, \& Kismali, 2016). Present investigation; aim the study of four endemic species, Valeriana parviflora (Trevis) Höck; $V$. rosaliana F.G.Mey.; V. triplinervis (Turcz.) Briq., and V. phylicoides (Turcz.) Briq., with restricted distribution in Mérida and Táchira states from Venezuela. These four species are shrubs that grow in high mountains at 2800 masl, have a strong odour, characteristic of this genus, and are used by local people as insect repellent, to aid sleep alterations and stomach disorders. Previously, our research group reported the chemical composition of $V$. parviflora essential oil collected in two different season of the year (rainy and dry). Linalool $(11.9 \%)$ and eugenol $(8.9 \%)$ were the major constituents in dry season, while o-xylol (16.2 $\%)$ and 3-methyl isovaleric acid (10.6\%) were the main compounds observed in the oil obtained in rainy season (Fernández, Rondón, Rojas, Morales, \& Rojas-Fermin, 2015).

The aim of this investigation is to determine qualitatively the presence of several secondary metabolites and to evaluate antimicrobial activity against Gram positive, Gram negative bacterial strain and yeasts of four Valeriana species. To the best of our knowledge there are no previous reports on this matter, thus, results are considered a contribution to the natural products investigation.

\section{MATERIALS AND METHODS}

Plant material: Fresh aerial parts of four endemic Valeriana L. species were collected from the Venezuelan Andes. Valeriana parviflora (Trevir) Hoeck (February 2015; Páramo Piedras Blancas, Mérida, 851'31" N - 71'57’06" W); V. phylicoides (Turcz.) Briq (June 2015; Páramo El Rosal, Táchira, 80’36.72" N \& 71 58 '53.76" W); V. triplinervis Turcz (October 2015; Sierra Nevada de Santo Domingo, Mérida, 8 48'6" $\mathrm{N} \& 70^{\circ} 49^{\prime} 40^{\prime \prime} \mathrm{W}$ ) and $V$. rosaliana Meyer (May 2012, La Fría, Táchira; $8^{\circ} 06$ '52.4” N - 71'54'57.6” W). Botanical identification was carried out by Ing. Luis Enrique Gámez, Herbarium MER, Faculty of Forestry and Environmental Sciences, University of Los Andes. Voucher specimens were deposited under the following codes: V. parviflora (MERR 02); V. phylicoides (986) and V. rosaliana (MERR 01) in Herbarium MERF, Faculty of Pharmacy and Bioanalysis, University of Los Andes. V. triplinervis (945458) was deposited at Herbarium MER, Faculty of Forestry and Environmental Sciences.

Extract preparation: Fresh aerial parts of Valeriana parviflora (400 g), V. rosaliana (640 g), V phylicoides (100 g) and $V$. triplinervis $(350 \mathrm{~g})$ were dried using a stove at 40 ${ }^{\circ} \mathrm{C}$ for 3 days, and then pulverized. Crude plant extracts were prepared by maceration at room temperature using $1 \mathrm{~L}$ of each different polar solvents of increasing polarity $[n$-hexane, dichloromethane $\left(\mathrm{CH}_{2} \mathrm{Cl}_{2}\right)$, ethyl acetate and methanol $(\mathrm{MeOH})]$. Solvents used for extractions were obtained from Merck. All extracts were filtered through a cotton plug followed by Whatman filter paper number 1 and concentrated under reduced pressure at $40{ }^{\circ} \mathrm{C}$ using rotary evaporator. Dried extracts were kept under refrigeration at $4{ }^{\circ} \mathrm{C}$ until phytochemical and microbiological analyses were performed.

Phytochemical Screening: Crude extracts were phytochemically evaluated to determine the presence of chemical constituents using 
standard procedures described by Harbone (Harbone, 1973).

Antimicrobial method: The microorganisms and yeast used for the antimicrobial method were Staphylococcus aureus (ATCC 25923), Enterococcus faecalis (ATCC 29212), Escherichia coli (ATCC 25992), Klebsiella pneumoniae (ATCC 23357), Pseudomonas aeruginosa (ATCC 27853), Candida albicans (DCCB 385) and Candida krusei (ATCC 6258).

The antimicrobial activity was carried out according to the disc diffusion assay described by (Velasco et al., 2007). The strains were maintained in agar conservation at room temperature. Each bacterial inoculum was incubated in $2.5 \mathrm{~mL}$ Müeller-Hinton broth (BBLTM®) at $37^{\circ} \mathrm{C}$ for 18 hours. The bacterial inoculum was diluted in sterile $0.85 \%$ saline to obtain turbidity visually comparable to McFarland $\mathrm{N}^{\mathrm{o}}$ 0.5 standard $\left(10^{6-8} \mathrm{CFU} / \mathrm{mL}\right)$. Every inoculum was spread over plates containing MüellerHinton agar. Paper filter discs $(6 \mathrm{~mm})$ saturated with $20 \mu \mathrm{L}$ of every extract ( $n$-hexane, dichloromethane, ethyl acetate and methanol) of Valeriana parviflora, $V$. rosaliana, $V$. triplinervis and $V$. phylicoides diluted 1:10 ratio with the same solvents used for each extract, were placed over the plates. These were preincubated at $4{ }^{\circ} \mathrm{C}$ for $18 \mathrm{~h}$ and finally incubated at $37{ }^{\circ} \mathrm{C}$ for 16-18 h. Antifungal activity was also evaluated following the disc diffusion methodology described by National Committee for Clinical Laboratory Standards (NCCLS, 2004). Twenty $\mathrm{mL}$ Müeller-Hinton agar (BBLTM $\left.{ }^{\circledR}\right)$ supplemented with glucose $(2 \%, \mathrm{w} / \mathrm{v})$ and methylene blue $(0.5 \mu \mathrm{g} / \mathrm{mL})$ were mixed with $1 \mathrm{~mL}$ of each yeast inoculum and turbidity was adjusted to McFarland $\mathrm{N}^{\circ} 1\left(3 \times 10^{8} \mathrm{CFU} / \mathrm{mL}\right)$ standard. The content of Petri dishes was allowed to solidify at room temperature and sterile control was also prepared. The inhibitory zone around the disc was measured and expressed in $\mathrm{mm}$. A positive control was also assayed to check the sensitivity of the tested organisms using the following antibiotics: Oxacillin $\mathbb{}(10 \mu \mathrm{g})$, Vancomycin $\AA(30 \mu \mathrm{g})$, Tobramycin ${ }^{\circledR}(30 \mu \mathrm{g})$, Aztreonam ${ }^{\circledR}(10 \mu \mathrm{g})$, Cefepime ${ }^{\circledR}(75 \mu \mathrm{g})$,
Ceftazidime ${ }^{\circledR}(30 \mu \mathrm{g})$, Fluconazole ${ }^{\circledR}(100$ $\mu \mathrm{g})$ and Voriconazole ${ }^{\circledR}(400 \mu \mathrm{g} / \mathrm{mL})$. A negative control was also included in the test using a filter paper disc saturated with $n$-hexane, dichloromethane ethyl acetate and methanol to discard any activity of these solvents against the microorganism assayed. The experiments were repeated at least twice. MIC was determined by dilution of each extract in $n$-hexane, dichloromethane ethyl acetate and methanol by pipetting $10 \mu \mathrm{L}$ of each dilution onto a filter paper disc. Dilutions of the extracts within a concentration range of $100-900 \mathrm{mg} / \mathrm{mL}$ were also carried out. Minimal inhibitory concentration was performed only on samples that showed growth inhibition and was defined as the lowest concentration that inhibited the visible bacterial growth (NCCLS, 2004).

Statistical analysis: One-way analysis of variance (ANOVA) was carried out to determine whether there is significant difference for antimicrobial activity either on the extracts or within the Valeriana species under investigation. In event of finding any significant difference, further analysis will be performed by using the Duncan's multiple ranges test. Significance level has been established at $\alpha=0.10$.

\section{RESULTS}

Phytochemical screening: In order to qualitatively identify the presence of main chemical constituents present in Valeriana L., species from Venezuelan Andes, a screening of crude methanolic extracts obtained from four Valeriana species were carried out. Results (Table 1) showed mainly presence of alkaloids, flavonoids, sterols, triterpenoids, saponins and tannins.

Antimicrobial activity: Antimicrobial activity was performed for $n$-hexane, dichloromethane, ethyl acetate and methanol extracts of Valeriana parviflora, $V$. rosaliana, $V$. triplinervis and $V$. phylicoides against Staphylococcus aureus, Enterococcus faecalis, Escherichia coli, Klebsiella pneumoniae, 
TABLE 1

Phytochemical screening of methanolic extracts obtained from four Valeriana L. species endemic of Venezuelan Andes

\begin{tabular}{|c|c|c|c|c|c|c|c|c|c|c|}
\hline \multirow{2}{*}{ Sample } & \multicolumn{3}{|c|}{ Alkaloids } & \multicolumn{2}{|c|}{ Flavonoids } & \multicolumn{3}{|c|}{ Sterols and triterpenes } & \multirow{2}{*}{$\begin{array}{c}\text { Saponis } \\
\text { FR }\end{array}$} & \multirow{2}{*}{$\begin{array}{c}\text { Tannins } \\
\mathrm{FeCl}_{3}\end{array}$} \\
\hline & DR & WR & MR & $\mathrm{NaOH}$ & PR & $\mathrm{KR}$ & L-B R & SR & & \\
\hline V. parviflora & +++ & ++ & ++ & +++ & +++ & ++ & +++ & +++ & +++ & +++ \\
\hline V. rosaliana & +++ & ++ & ++ & ++ & ++ & ++ & +++ & +++ & + & +++ \\
\hline$V$ triplinervis & +++ & ++ & ++ & +++ & ++ & ++ & +++ & +++ & + & +++ \\
\hline V. phylicoide & +++ & ++ & ++ & ++ & +++ & + & +++ & +++ & + & +++ \\
\hline
\end{tabular}

+: less abundant; ++: medium; +++: high abundance; -: absence. DR: Dragendorff reagent; WR: Wagner reagent; MR: Mayer reagent; $\mathrm{NaOH}$ 10\% solution; Pews reagent; KR: Komarowsky reagent; LB R: Lieberman- Bouchard reagent; SR: Salkowky reagent; FR: Foam reagent; $\mathrm{FeCl}_{3} 5 \%$ solution.

Pseudomonas aeruginosa, Candida albicans and Candida krusei. All extracts showed effectiveness against only Gram positive bacterial strain, $S$. aureus. Results are shown in table 2 and table 3. Statistical analysis showed no significant differences on the different polarity extracts assayed with respect to antimicrobial activity against $S$. aureus $(\mathrm{P}>0.10)$.

\section{DISCUSSION}

Nearly 150 different compounds have been found in Valeriana genus (Backlun \& Moritz, 1998). Details on some of these compounds are given in various phytochemical investigations. For instance, phenolic compounds such as tannins and flavonoids isolated as linarin and hesperidine with activity on the Central Nervous System has been identified from some Valeriana species (Marder et al., 2003; Fernández, Wasowski, Paladini, \& Marde, 2004). It is important to state that, these components are observed in all samples analyzed, in present investigation, by using $\mathrm{FeCl}_{3} 5 \%$, NaOH $10 \%$ and Pew's reactive, respectively. Furthermore, Valeriana genus is recognized mainly for the presence of alkaloids (pyridine derivatives) and terpenoids (iridoids-monoterpenes and valepotriates) as the major chemical constituents found on extracts of these species (Jiang, Zhang, Liu \& Fang, 2007; Zhou, Fang, Gong, Duan, \& Liu, 2009; Patoĉka \& Jakl, 2010). Regarding alkaloids, actinidine, chatinine, valerianine and valerene, are the most common isolated from this genus. Investigations have pointed these alkaloids as responsible for the psychoactivity observed in Valeriana officinalis L., traditionally used to treat sleeping disorders and anxiety. Researchers believe that, those alkaloids may act through an interaction with GABA and benzodiazepine receptors (Miyasaka \& Soares, 2006). In present study, abundant presence of alkaloids were observed in all samples assayed, thus, these species are considered interesting for further investigations related to the sleep inducer effect. Other secondary metabolites present in Valeriana extracts are saponins, triterpenes and steroids (Backlun \& Moritz, 1998).

Regarding antibacterial activity, according to results (Table 2 and Table 3), all extracts assayed showed growth inhibition against $S$. aureus, which is responsible for a number of serious human infectious diseases (Tong et al., 2015; Blomfeldt, Eskesen, Aamot, Leegaard, \& BiØrnholt, 2016) with MIC values ranging between 150 to $500 \mathrm{mg} / \mathrm{mL}$. The most active extract was $n$-hexane from $V$. triplinervis showing the highest inhibition zone (16 mm), MIC value of $116 \mathrm{mg} / \mathrm{mL}$, followed by $V$. rosaliana $(15 \mathrm{~mm})$; with $150 \mathrm{mg} / \mathrm{mL}$; while the lowest activity was observed for $V$. parviflora and $V$. phylicoides (inhibition zone $<11 \mathrm{~mm}$ ).

Furthermore, dichloromethane extract from $V$. triplinervis showed an inhibition zone of $15 \mathrm{~mm}$ with MIC value of $200 \mathrm{mg} / \mathrm{mL}$. However, same solvent extracts from $V$. rosaliana and $V$. phylicoides exhibited a rather poor activity against $S$. aureus while $V$. parviflora showed no activity at all. Ethyl acetate extracts exhibited the lowest antibacterial activity 

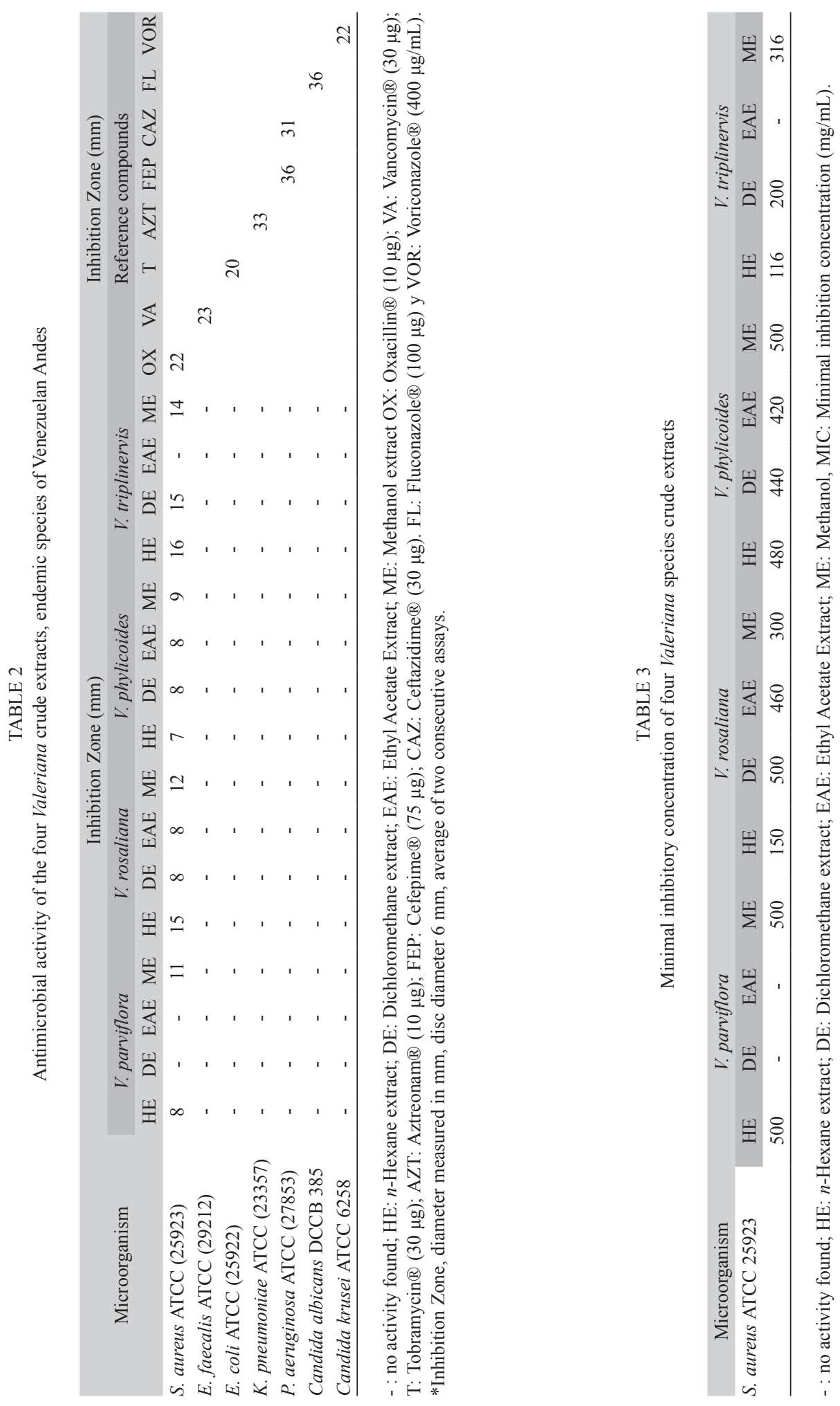
against $S$. aureus since only $V$. rosaliana and $V$. phylicoides extracts showed activity with MIC values over $400 \mathrm{mg} / \mathrm{mL}$. Finally, methanol extract of $V$. triplinervis showed an inhibition zone of $14 \mathrm{~mm}$, at MIC of $316 \mathrm{mg} / \mathrm{mL}$. None of the extracts assayed showed any activity against the two yeasts tested.

According to statistical analysis, significant difference was observed between the four Valeriana species analyzed $(\mathrm{P}<0.10)$ with respect to the minimal inhibitory concentration (MIC) values against $S$. aureus. Furthermore, Duncan's multiple ranges test probed that two groups, not clearly separately, are formed within these species; parviflora-phylicoides and triplinervis-rosaliana, being the second group that exhibited the best antibacterial activity against $S$. aureus.

Previous investigations on antimicrobial activity of Valeriana species have revealed that methanolic and aqueous extracts show the strongest activity, suggesting that polar compounds might be responsible for such activity (Sati et al., 2011). Additionally, essential oils isolated from different Valeriana species have shown significant activity against a wide spectrum of bacterial strains (Tzakou, Couladis, Pavlovic, \& Sokovic, 2004; Wang et al., 2010). This activity may be attributed to secoiridoids and secoiridoids glucosides frequently found in Valeriana species that have exhibited antimicrobial properties (Nadinic et al., 2002), as well as to flavonoids and tannins presents in the extracts (Table 1).

Evidence on the presence of secondary metabolites such as alkaloids, flavonoids, tannins, steroids, terpenoids (valepotriates and baldrinal) have been observed in Valeriana parviflora, $V$. rosaliana, $V$. triplinervis and $V$. phylicoides extracts. Regarding antibacterial activity, all extracts showed effectiveness against only Gram-positive bacterial strain, $S$. aureus, which is responsible for a number of serious human infectious diseases. This investigation, aims to provide value scientific information that might be useful for further studies on the therapeutic potential of these species, growing at Venezuelan Andes.

\section{ACKNOWLEDGMENTS}

Authors wish to thank CDCHT, Universidad de Los Andes (FA-528-12-08) and FONACIT (2013001838) for the financial support.

\section{RESUMEN}

Actividad antimicrobiana de cuatro especies de Valeriana (Caprifoliaceae) endémicas de los Andes venezolanos. El género Valeriana, está representado en Venezuela por 16 especies, 9 de las cuales son endémicas de Los Andes y crecen en las altas montañas a $2800 \mathrm{msnm}$. En esta investigación cuatro especies fueron analizadas para determinar los principales metabolitos secundarios y la actividad antimicrobiana de los extractos obtenidos de las partes aéreas de Valeriana parviflora, V. rosaliana, $V$. triplinervis y $V$. phylicoides. Compuestos como alcaloides, flavonoides, taninos, estroles, triterpenos y saponinas fueron detectados cualitativamente en todos los extractos metanólicos ensayados. La intensidad del color o la formación de un precipitado se tomaron como respuesta positiva para estos análisis. Actividad antimicrobiana fue evaluada frente a bacterias Gram positivas, Gram negativas y levaduras, usando el método de difusión en discos. Los extractos en $n$-hexano de $V$. triplinervis y $V$. rosaliana mostraron la mayor eficiencia frente a Staphylococcus aureus, mostrando zonas de inhibición de $16 \mathrm{~mm}$ y $15 \mathrm{~mm}$ con valores de CIM (Concentración Inhibitoria Mínima) observados a $116 \mathrm{mg} / \mathrm{mL}$ y $150 \mathrm{mg} / \mathrm{mL}$, respectivamente. Los extractos con diclorometano y metanol de $V$. triplinervis y metanol de $V$. rosaliana revelaron moderada actividad (CIM entre 200 y $316 \mathrm{mg} / \mathrm{ml}$ ), mientras actividad muy leve se observó en los extractos de $V$. phylicoides y $V$. parviflora (CIM > $420 \mathrm{mg} / \mathrm{mL}$ ). Ninguno de los extractos ensayados mostraron actividad frente a Candida albicans y Candida krusei. Los análisis estadísticos mostraron que no hay diferencia significativa entre los solventes de diferentes polaridades con relación a la actividad antimicrobiana frente a $S$. aureus $(\mathrm{P}>0.10)$, sin embargo, sí se observó diferencia significativa $(\mathrm{P}<0.10)$, entre las especies de Valeriana ensayadas con respecto a la concentración inhibitoria mínima (CIM).

Palabras clave: Valeriana; actividad antimicrobiana; fitoquímica; Venezuela.

\section{REFERENCES}

Aydin, F., Dikmen, B., \& Kismali, G. (2016). The potential cytotoxic effects of Valeriana officinalis extracto on protate cáncer cell line DU-145 and PC-3. Toxicology Letters, 258, S299.

Backlun, A., \& Moritz, T. (1998). Phylogenetic implications of an expanded valepotriate distribution in the 
Valerianaceae. Biochemical Systematic and Ecology, 26, 309-335.

Bell, C., \& Dologhue, M. (2005). Phylogeny and biogeography of Valerianaceae (Dipsacales) with special reference to the South America valerians. Organims, Diversity \& Evolution, 5, 137-149.

Bhatt, I., Dauthal, P., Rawat, S., Gaira, K., Jugran, A., Rawal, R., \& Dhar, U. (2012). Characterization of essential oil composition, phenolic content, and antioxidant properties in wild and planted individuals of Valeriana jatamansi Jones. Scientia Horticulturae, $136,61-68$

Blomfeldt, A., Eskesen, A., Aamot, H., Leegaard, T., \& BiØrnholt, J. (2016) Population-based epidemiology of Staphylococcus aureus bloodstream infection: clonal complex 30 genotype is associated with mortality. European Journal Clinical Microbiology \& Infectious Diseases, 35, 803-13.

Celis, C., Rincón, J., \& Guerrero, M. (2007). Actividad farmacológica sobre el Sistema Nervioso Central del extracto etanólico y fracción alcaloidal de Valeriana pavonii. Revista Colombiana de Ciencias Químicas y Farmacéuticas, 36, 11-22.

Chen, H. W., He, X. H., Yuan, R., Wei, B. J., Chen, Z., Dong, J. X., \& Wang, J. (2016). Sesquiterpenes and monoterpenoid with acetylcholinesterase (AchE) inhibitory activity from Valeriana officinalis var. latiofolia in vitro and in vivo. Fitoterapia, 110, 142-149.

Fernández, S., Rondón, M., Rojas, J., Morales, A., \& Rojas-Fermín, L. (2015). Comparison of the Chemical Composition of Valeriana parviflora Essential Oils Collected in the Venezuelan Andes in two Different Seasons. Natural Product Communication, 10, 657-659.

Fernández, S., Wasowski, C., Paladini, A., \& Marde, M. (2004). Sedative and sleep.enhancing properties of linarin, a flavonoid-isolated from Valeriana officinalis. Pharmacology Biochemistry and Behavior, 77, 399-404.

Gilani, A., Khan, A. U., Jabeen, Q., Subhan, F., \& Ghafar, R. (2005). Antispasmodic and blood pressure lowering effects of Valeriana wallichii mediated through $\mathrm{K}^{+}$channel activation. Journal of Ethnopharmacology, 100, 347-352.

Harborne, J. B. (1973). Phytochemical methods, A Guide to Modern Techniques of plant analysis (pp. 49-188). Chapman and Hall, London, Ltd.

Houghton, P. (1988). The biological activity of Valerian and related plant. Journal of Ethonopharmacology, $22,121-142$
Houghton, P. (1998). The scientific basis for the reputed activity of Valerian. Journal of Pharmacy and Pharmacology, 51, 505-512.

Jiang, X., Zhang, J. C., Liu, Y. W., \& Fang, Y. (2007). Studies on chemical constituents of Valeriana officinalis (in Chinese). Zhong Yao Cai, 30, 1391-1393.

Marder, M., Viola, H., Wasowski, C., Fernández, S., Medina, J., \& Paladini, A. (2003). 6-methylapigenin and hesperidin: new valeriana flavonoids with activity on the CNS. Pharmacology Biochemitry and Behavior, $75,537-545$.

Miyasaka, L., \& Soares, B. (2006). Valerian for anxiety disorders. Cochrane Database of Systematic Reviews 18, CD004515. DOI: 10.1002/14651858.CD004515. pub2

Nadinic, E., Penna, C., Saavedra, C., Coussio, J., Gutkind, G., \& Debenedetti, S. (2002). Aislamiento de los Compuestos con Actividad Antimicrobiana de Extractos de Gentianella achalensis (Gilg) Ho \& Liu (Gentianaceae). Acta Farmacéutica Bonaerenses, 21, 123-130.

National Committee for Clinical Laboratory Standards (NCCLS). (2004). Performance standards for antimicrobial disk sus-ceptibility testing. Fourteenth informational supplement. Wayne, Pa: NCCLS document M100-S14.

Patoĉka, J., \& Jakl, J. (2010). Biomedically relevant chemical constituents of Valeriana officinalis. Journal of Applied Biomedicine, 8, 11-18.

Potdar, V. H., Lole, V. D., \& Patil, S. S. (2011). In-vitro Anthelmintic Activity of Rhizomes of Valeriana wallichii DC (Valerianaceae) Against Pheretima posthuma. Indial. Journal of Pharmaceutical Education and Research, 45, 83-85.

Sati, S. C., Khulbe, K., \& Joshi, S. (2011). Antibacterial Evaluation of the Himalayan Medicinal Plant Valeriana wallichii DC. (Valerianaceae). Research Journal of Microbiology, 6, 289-296.

Sridharan, S., Mohankumar, K., Kumar, S., Sankaramourthy, D., Ronsard, L., Subramanian, K., ... Sadras, S. (2015). Neuroprotective effect of Valeriana wallichii rhizome extract against the neurotoxin MPTP in C57BL/6 mice. Neuro Toxicology, 51, 172-183.

Tan, Y. Z., Yong, Y., Dong, Y. H., Wang, R. J., Li, H. X., Zhang, H., ... Xie, X. F. (2016). A new secoiridoid glycoside and a new sesquiterpenoid glycoside from Valeriana jatamansi with neuroprotective activity. Phytochemistry Letters, 17, 177-180.

Tong, S., Davis, J., Eichenberger, E., Holland, T., \& Fowler, V. (2015). Staphylococcus aureus infections: epidemiology, pathophysiology, clinical manifestations, and management. Clinical Microbiology Review, 28, 603-661. 
Tzakou, O., Couladis, M., Pavlovic, M., \& Sokovic, M. (2004). Composition and antifungical activity of the oil from aerial parts rizhomes of Valeriana dioscoridis from Greece. Journal of Essential Oil Research, $16,500-503$.

Velasco, J., Rojas, J., Salazar, P., Rodríguez, M., Díaz, T., Morales, A., \& Rondón, M. (2007). Antibacterial activity of the essential oil of Lippia oreganoides against multiresistant bacterial strains of nosocomial origin. Natural Product Communication, 2, 85-88.

Wang, J., Zhao, J., Liu, H., Zhou, L., Liu, Z., Wang, J. ... Yang, F. (2010). Chemical Analysis and Biological
Activity of the Essential Oils of Two Valerianaceous Species from China: Nardostachys chinensis and Valeriana officinalis. Molecules, 15, 6411-6422.

Xena, E. N. (1993). Contribución al estudio del género Valeriana L. en Venezuela: Distribución geográfica, caracteres morfoanatómicos, cariológicos y palinológicos de interés taxonómico y evolutivo. Acta Botánica Venezuelica, 16, 105-115.

Zhou, Y., Fang, Y., Gong, Z., Duan, X., \& Liu, Y. (2009). Two news terpenoids from Valeriana officinalis. Chinese Journal of Natural Medicine, 7, 270-273. 